\title{
WIŃCZYSŁAW JASTRZĘBSKI
}

Katolicki Uniwersytet Lubelski Jana Pawła II

\section{WPŁYW NOWELIZACJI KODEKSU POSTĘPOWANIA KARNEGO NA ZAKRES KARNOPROCESOWYCH UPRAWNIEŃ ŻANDARMERII WOJSKOWEJ}

\section{UWAGI WPROWADZAJĄCE}

Z dniem 1 lipca 2015 r. weszła w życie nowelizacja polskiego prawa karnego procesowego ${ }^{1}$ zmieniająca w sposób zasadniczy dotychczasową filozofię postępowania karnego. Wśród jej celów wymienia się m. in. ograniczenie roli postępowania przygotowawczego i zbudowanie modelu rozprawy opartego na zasadzie pełnej kontradyktoryjności ${ }^{2}$. Rzeczona nowelizacja przyniosła również zmianę właściwości procesowej Żandarmerii Wojskowej. Zgodnie z nową treścią art. 312 k.p.k dotychczasowe uprawnienia Policji przysługują także Żandarmerii Wojskowej w zakresie jej właściwości. Tym samym uprawnienia procesowe Żandarmerii Wojskowej zostały znacznie rozszerzone, zarówno w sferze podmiotowej jak i przedmiotowej, w związku z powiązaniem ich bezpośrednio z właściwością określoną w Ustawie z dnia 24 sierpnia 2001 r. o Żandarmerii Wojskowej i wojskowych organach porządkowych ${ }^{3}$. W celu określenia

\footnotetext{
1 Ustawa z dnia 27 września 2013 r. o zmianie ustawy - Kodeks postępowania karnego oraz niektórych innych ustaw, Dz.U. z 2013 r. poz. 1247 ze zm.

2 D. KaCzOrkiewicz, Forma postępowania przygotowawczego w świetle zmian Kodeksu postępowania karnego z 2013 r., [w:] Reforma prawa karnego, red. I. SEPIOŁO-JANKowsKa, Warszawa 2014, s. 463-464.

3 Tekst jedn. Dz.U. z 2013 r., poz. 568 ze zm., dalej jako ŻWU.
} 
skutków przedmiotowej zmiany zasadne jest przedstawienie jej na tle podstawowych informacji na temat struktury i zadań realizowanych przez Żandarmerię Wojskową.

\section{STRUKTURA ŻANDARMERII WojSKoWej}

Żandarmeria Wojskowa (ŻW) została utworzona w Siłach Zbrojnych Rzeczypospolitej Polskiej z dniem 1 września 1990 r. ${ }^{4}$ w nawiązaniu do tradycji sięgających czasów Księstwa Warszawskiego ${ }^{5}$. Obowiązująca od dnia 1 stycznia 2002 r. Ustawa o Żandarmerii Wojskowej i wojskowych organach porządkowych jest podstawowym dokumentem definiującym jej strukturę i kompetencje. Ponadto zadania tej służby zostały uszczegółowione w rozporządzeniach wydanych na podstawie niniejszej ustawy, jak też określone $\mathrm{w}$ szeregu innych aktów normatywnych $\mathrm{w}$ randze ustaw i rozporządzeń6.

Porównując powinności Żandarmerii Wojskowej w Siłach Zbrojnych RP z obowiązkami Policji, do podobieństw należy zaliczyć obowiązek zapewnienia bezpieczeństwa obywateli oraz utrzymywania porządku publicznego. Cechą wyróżniającą Żandarmerię Wojskową stanowi natomiast

\footnotetext{
4 Na mocy rozkazu Ministra Obrony Narodowej z 18 kwietnia 1990 r.

5 Oficjalna strona Żandarmerii Wojskowej: www.zw.wp.mil.pl.

6 Do ustaw określających zadania ŻW należą m.in. Ustawa z dnia 6 czerwca 1997 r. Kodeks postępowania karnego, Dz.U. z 1997 r. Nr 89, poz. 555 ze zm., Ustawa z 24 sierpnia 2001 r. Kodeks postępowania w sprawach o wykroczenia, tekst jedn. Dz.U. z 2013 r., poz. 395 ze zm., dalej jako k.p.w, Ustawa z dnia 10 października 1999 r. Kodeks karny skarbowy, tekst jedn. Dz.U. z 2013 r., poz. 186 ze zm., dalej jako k.k.s., Ustawa z dnia 6 kwietnia 1990 r. o Policji, tekst jedn. Dz.U. z 2011 r. Nr 287, poz. 1687 ze zm., Ustawa z dnia 20 czerwca 1997 r. Prawo o ruchu drogowym, tekst jedn. Dz.U. z 2012 r., poz. 1137 ze zm., Ustawa z dnia 9 października 2009 r. o dyscyplinie wojskowej, Dz.U. z 2009 r. Nr 190, poz. 1474 ze. zm., Ustawa z dnia 26 października 1982 r. o wychowaniu w trzeźwości i przeciwdziałaniu alkoholizmowi, tekst jedn. Dz.U. z 2012 r., poz. 1356 ze zm., Ustawa z dnia 21.5.1999 r. o broni i amunicji, tekst jedn. Dz.U. z 2012 r., poz. 576 ze zm., Ustawa z dnia 17 listopada 1964 r. Kodeks postępowania cywilnego, tekst jedn. Dz.U. z 2014 r., poz. 101 ze zm., Ustawa z dnia 17 czerwca 1966 r. o postępowaniu egzekucyjnym w administracji, tekst jedn. Dz.U. z 2012 r., poz. 1015 ze zm.
} 
fakt wykonywania przez nią zadań na rzecz Sił Zbrojnych $\mathrm{RP}^{7}$. Działa ona wówczas jako wsparcie policyjne dla dowódców wszystkich szczebli dowodzenia ${ }^{8}$. Zakres realizowanych zadań umiejscawia ŻW na styku pomiędzy Siłami Zbrojnymi, ludnością cywilną oraz różnorodnymi instytucjami odpowiedzialnymi za bezpieczeństwo i przestrzeganie prawa?.

Żandarmeria Wojskowa jest wyodrębnioną i wyspecjalizowaną służbą, wchodzącą w skład Sił Zbrojnych $\mathrm{RP}^{10}$, a Komendant Główny ŻW podlega bezpośrednio Ministrowi Obrony Narodowej ${ }^{11}$. Żandarmerię Wojskową tworzą ${ }^{12}$ :

1) Komenda Główna Żandarmerii Wojskowej,

2) terenowe jednostki organizacyjne Żandarmerii Wojskowej w postaci oddziałów w Bydgoszczy, Elblągu, Krakowie, Warszawie, Szczecinie i Żaganiu oraz wydziałów w Bemowie Piskim, Gdyni, Lublinie, Łasku, Olesznie, Poznaniu, Rzeszowie, Ustce, Wędrzynie i Wrocławiu.

3) specjalistyczne jednostki organizacyjne Żandarmerii Wojskowej.

W skład oddziałów lub wydziałów ŻW mogą wchodzić zamiejscowe komórki wewnętrzne w postaci placówek ŻW ${ }^{13}$.

W strukturze Żandarmerii Wojskowej można wyróżnić trzy piony funkcjonalne: dochodzeniowo-śledczy, prewencyjny oraz administracyjno-logistyczno-techniczny ${ }^{14}$. Zadania pionu dochodzeniowo-śledczego ŻW realizuje Zarząd Dochodzeniowo-Śledczy na szczeblu Komendy Głównej Żandarmerii Wojskowej, wydziały i sekcje w terenowych jednostkach organizacyjnych, a także żołnierze placówek ŻW.

7 A. Rochnowski, M. Hausman, Analiza kryminalna w Żandarmerii Wojskowej, «Kwartalnik Bellona» 1/2015, s. 173.

8 T. Chiniewicz, S. Korzeniowski, P. PŁonka, Żandarmeria $w$ działaniach operacyjnych, Mińsk Mazowiecki 2011, s. 6.

9 M. Witczak, Podstawowe zadania Żandarmerii Wojskowej, [w:] Przeciwdziałanie zagrożeniem niemilitarnym. Zasadnicze aspekty współpracy Żandarmerii Wojskowej i Policji, red. P. GuŁa, P. PŁonka, Legionowo 2009, s. 22.

10 Art. 1 ŻWU.

11 Art. 6 ust. $2 \dot{Z} W U$.

12 Art. 7 ŻWU.

13 Bliższe dane na temat struktury ŻW, w tym umiejscowienia placówek ŻW na stronie: www.zw.wp.mil.pl.

14 Art. 8 ust. 1 ŻWU. 


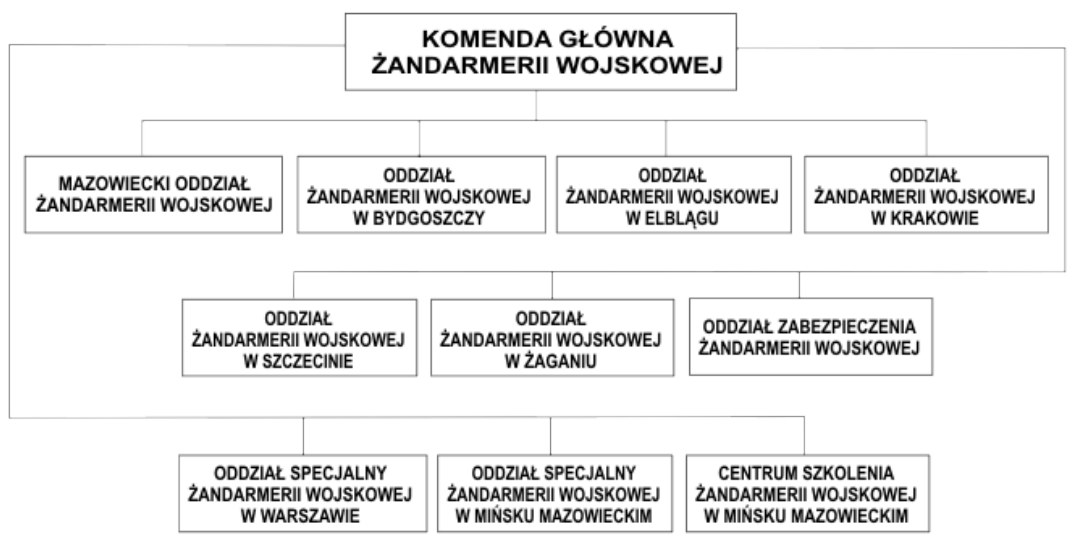

Rysunek 1. Struktura ŻW ${ }^{15}$.

Wśród zadań niniejszego pionu wyróżnia się działania dochodzeniowo-śledcze (zakres procesowy), operacyjno-rozpoznawcze (o charakterze służebnym wobec procesu karnego ${ }^{16}$ ), kryminalistyczne, analityczno-informacyjne, ewidencji operacyjnej oraz badania psychofizjologiczne ${ }^{17}$. Ponadto Żandarmeria Wojskowa posiada psy do nawęszania środków odurzających i materiałów wybuchowych. $Z$ uwagi na realizowane zadania Żandarmeria Wojskowa wraz z Prokuraturą Wojskową określane są jako wojskowe organy ścigania karnego ${ }^{18}$.

15 Źródło: www.zw.wp.mil.pl (dostęp 23 kwietnia 2015 r.).

16 W. Kubica, A. Hatalska-GorzKI, Stużba policyjna, czy kontrwywiad? Rzecz o teoretycznym sporze kompetencyjnym, «Wojskowy Przegląd Prawniczy» 1/2011, s. 26.

$17 \$ 13$ Zarządzenia nr 46/MON Ministra Obrony Narodowej z dnia 28 września 2011 r. w sprawie szczegółowego zakresu działania Komendy Głównej Żandarmerii Wojskowej i szczegółowego zakresu działania Centrum Szkolenia Żandarmerii Wojskowej, Dz.U. MON z 2011 r. Nr 20, poz. 294 oraz załączniki Zarządzenia nr 53/ MON Ministra Obrony Narodowej z dnia 8 listopada 2011 r. w sprawie szczegółowych zakresów działania jednostek organizacyjnych Żandarmerii Wojskowej, Dz.U. MON z 2011 r. Nr 23, poz. 336.

18 F. PrusAK, Żandarmeria Wojskowa i wojskowe organy porządkowe, [w:] Żandarmeria Wojskowa w systemie bezpieczeństwa wewnętrznego państwa, red. B. WiśnIEWski, P. PŁonka, Mińsk Mazowiecki 2010, s. 50. 


\section{ZADANIA ŻANDARMERII WOJSKOWEJ}

Żandarmeria Wojskowa posiada uprawnienia wobec żołnierzy ${ }^{19}$ :

1) pełniących czynną służbę wojskową,

2) niebędących w czynnej służbie wojskowej w czasie noszenia przez nich mundurów oraz odznak i oznak wojskowych.

Ponadto ŻW jest właściwa wobec osób cywilnych, tj.:

1) pracowników zatrudnionych w jednostkach wojskowych:

a) w związku $z$ ich zachowaniem się podczas pracy w tych jednostkach,

b) $\mathrm{w}$ związku z popełnieniem przez nich czynu zabronionego przez ustawę pod groźbą kary, wiążącego się z tym zatrudnieniem,

2) osób przebywających na terenach lub w obiektach jednostek wojskowych,

3) innych osób podlegających orzecznictwu sądów wojskowych albo jeżeli wynika to z odrębnych przepisów,

4) osób niebędących żołnierzami, jeżeli współdziałają z wyżej wymienionymi żołnierzami lub osobami cywilnymi w popełnieniu czynu zabronionego przez ustawę pod groźbą kary albo też jeżeli dokonują czynów zagrażających dyscyplinie wojskowej albo czynów przeciwko życiu lub zdrowiu żołnierza albo mieniu wojskowemu.

Właściwość Żandarmerii Wojskowej obejmuje także żołnierzy sił zbrojnych państw obcych, przebywających na terytorium Rzeczypospolitej Polskiej oraz członków ich personelu cywilnego, jeżeli pozostają w związku z pełnieniem obowiązków służbowych, o ile umowa międzynarodowa, której Rzeczpospolita Polska jest stroną, nie stanowi inaczej.

Do podstawowych zadań Żandarmerii Wojskowej należy ${ }^{20}$ :

1) zapewnienie przestrzegania dyscypliny wojskowej,

2) ochranianie porządku publicznego na terenach i obiektach jednostek wojskowych oraz w miejscach publicznych,

3) ochranianie życia i zdrowia ludzi oraz mienia wojskowego przed zamachami,

19 Art. 3 ust. $2 \dot{Z} W U$.

20 Art. 4 ust. 1 ŻWU. 
4) wykrywanie przestępstw i wykroczeń, w tym skarbowych, zgodnie z właściwością podmiotową ŻW, ujawnianie i ściganie ich sprawców oraz ujawnianie i zabezpieczanie dowodów tych przestępstw i wykroczeń,

5) zapobieganie popełnianiu przestępstw i wykroczeń, w tym skarbowych oraz zjawiskom patologicznym, a w szczególności: alkoholizmowi i narkomanii w Siłach Zbrojnych,

6) dokonywanie analizy oświadczeń o stanie majątkowym żołnierzy zawodowych i przedstawianie Ministrowi Obrony Narodowej wniosków w tym względzie,

7) współdziałanie z polskimi i zagranicznymi organami i służbami właściwymi w sprawach bezpieczeństwa i porządku publicznego oraz policjami wojskowymi,

8) zwalczanie klęsk żywiołowych, nadzwyczajnych zagrożeń środowiska i likwidowanie ich skutków oraz czynne uczestnictwo w akcjach poszukiwawczych, ratowniczych i humanitarnych, mających na celu ochronę życia i zdrowia oraz mienia,

9) wykonywanie innych zadań określonych w odrębnych przepisach.

Powyższe zadania zgodnie z ŻWU realizowane są m.in. poprzez wykonywanie czynności procesowych w zakresie i na zasadach przewidzianych w przepisach o postępowaniu karnym i karnym skarbowym, zabezpieczanie śladów i dowodów popełnienia przestępstw i wykroczeń, sporządzanie ekspertyz i opinii kryminalistycznych, poszukiwanie sprawców przestępstw i wykroczeń oraz zaginionych żołnierzy, a także poszukiwanie utraconych przez jednostki wojskowe: broni, amunicji, materiałów wybuchowych i innego mienia wojskowego oraz materiałów zawierających informacje niejawne ${ }^{21}$.

\section{4. ŻANDARMERIA WOJSKOWA JAKO ORGAN PROCESOWY}

Żandarmeria Wojskowa jest organem procesowym prowadzącym postępowania w sprawach o przestępstwa i wykroczenia, a także o przestępstwa skarbowe i wykroczenia skarbowe. Dotychczasowe uprawnienia

21 Por. art. 4 ust. 2 ŻWU. 
Żandarmerii Wojskowej w sprawach o przestępstwa wynikały z treści art. 663 k.p.k stanowiącego, że w sprawach podlegających orzecznictwu sądów wojskowych uprawnienia i obowiązki procesowe Policji dotyczą także Żandarmerii Wojskowej. Artykuł 663 k.p.k został uchylony ${ }^{22}$ i przestał obowiązywać z dniem 1 lipca $2015 \mathrm{r}$.

Warto przypomnieć, że od 1 stycznia 2009 r. na podstawie art. 647 k.p.k. orzecznictwu sądów wojskowych podlegają sprawy żołnierzy w czynnej służbie wojskowej o przestępstwa:

1) określone w rozdziałach XXXIX-XLIV k.k. (część wojskowa),

2) popełnione przeciwko organowi wojskowemu lub innemu żołnierzowi,

3) popełnione podczas pełnienia lub $\mathrm{w}$ związku $\mathrm{z}$ pełnieniem obowiązków służbowych, w obrębie obiektu wojskowego lub wyznaczonego miejsca przebywania, na szkodę wojska lub z naruszeniem obowiązku wynikającego ze służby wojskowej,

4) popełnione za granicą, podczas użycia lub pobytu Sił Zbrojnych Rzeczypospolitej Polskiej poza granicami państwa, w rozumieniu Ustawy z 17 grudnia 1998 r. o zasadach użycia lub pobytu Sił Zbrojnych Rzeczypospolitej Polskiej poza granicami państwa ${ }^{23}$.

Ponadto orzecznictwu sądów wojskowych podlegają sprawy:

1) pracowników wojska o przestępstwa przeciwko zasadom pełnienia służby i przeciwko mieniu wojskowemu ${ }^{24}$ oraz o przestępstwa popełnione za granicą, podczas użycia lub pobytu Sił Zbrojnych Rzeczypospolitej Polskiej poza granicami państwa,

2) żołnierzy sił zbrojnych państw obcych, przebywających na terytorium Rzeczypospolitej Polskiej oraz członków ich personelu cywilnego, o przestępstwa popełnione w związku z pełnieniem obowiązków służbowych, chyba że umowa międzynarodowa, której Rzeczpospolita Polska jest stroną, stanowi inaczej.

Sądy wojskowe, zgodnie z treścią art. 648 k.p.k., rozpoznają także sprawy o współdziałanie w popełnieniu przestępstw określonych

\footnotetext{
22 Ustawa z dnia 27 września 2014 r. o zmianie ustawy - Kodeks ...

23 Tekst jedn. Dz.U. z 2014 r., poz. 1510.

24 Rozdziały XLIII k.k. i XLIV k.k.
} 
w części wojskowej Kodeksu karnego, jak również o przestępstwa poplecznictwa i paserstwa z nimi związane.

Powyższy zakres podmiotowo-przedmiotowy spraw podlegających orzecznictwu sądów wojskowych w praktyce ograniczał dotychczasową działalność procesową Żandarmerii Wojskowej do przestępstw popełnianych przez żołnierzy na terenie jednostek wojskowych.

Z dniem 1 lipca 2015 r. nie zmienił się zakres właściwości sądów wojskowych, a co za tym idzie prokuratur wojskowych, wynikający $\mathrm{z}$ art. 647 k.p.k. i art. 648 k.p.k. Natomiast w wyniku nowelizacji art. 312 k.p.k. uprawnienia procesowe Żandarmerii Wojskowej zostały znacznie rozszerzone w związku z powiązaniem ich z art. 3 ust. 2 ŻWU ${ }^{25}$. Organy Żandarmerii Wojskowej uzyskały w ten sposób uprawnienia przysługujące dotychczas poza Policją organom Straży Granicznej, Agencji Bezpieczeństwa Wewnętrznego, Służbie Celnej oraz Centralnemu Biuru Antykorupcyjnemu.

Uprawnienia Żandarmerii Wojskowej w zakresie prowadzenia czynności wyjaśniających w sprawach o wykroczenia nie uległy zmianie i nadal wynikają z treści art. $85 \$ 2$ k.p.w w zw. z art. $10 \$ 1$ k.p.w Na tej podstawie Żandarmerii Wojskowej przysługują uprawnienia i obowiązki procesowe Policji, w stosunku do osób podlegających orzecznictwu sądów wojskowych w sprawach o wykroczenie, z tym zastrzeżeniem, że oskarżycielem publicznym w tego rodzaju sprawach może być wyłącznie prokurator wojskowy. Orzecznictwu sądów wojskowych podlegają sprawy o wykroczenia popełnione przez żołnierzy w czynnej służbie wojskowej:

1) przeciwko organowi wojskowemu lub innemu żołnierzowi,

2) podczas lub w związku z pełnieniem obowiązków służbowych, w obrębie obiektu wojskowego lub wyznaczonego miejsca przebywania, na szkodę wojska lub z naruszeniem obowiązku wynikającego ze służby wojskowej, podczas lub w związku z pełnieniem obowiązków służbowych, w obrębie obiektu wojskowego lub wyznaczonego miejsca

25 Odmiennie D. KACZORkiewicz, op. cit., s. 465. - oceniając zmianę art. 312 k.p.k. jako jedynie porządkującą. 
przebywania, na szkodę wojska lub z naruszeniem obowiązku wynikającego ze służby wojskowej,

3) za granicą, podczas użycia lub pobytu Sił Zbrojnych Rzeczypospolitej Polskiej poza granicami państwa, w rozumieniu ustawy z dnia 17 grudnia 1998 r. o zasadach użycia lub pobytu Sił Zbrojnych Rzeczypospolitej Polskiej poza granicami państwa.

Orzecznictwu sądów wojskowych w sprawach o wykroczenia nie podlegają pracownicy cywilni wojska, natomiast - analogicznie jak w sprawach o przestępstwa - podlegają sprawy żołnierzy sił zbrojnych państw obcych oraz członków ich personelu cywilnego.

W sprawach o przestępstwa skarbowe i wykroczenia skarbowe podstawą prowadzenia postępowań przygotowawczych przez Żandarmerię Wojskową jest art. $134 \$ 1$ pkt 4 k.k.s. Właściwość podmiotowo-przedmiotowa Żandarmerii Wojskowej w sprawach „skarbowych” pozostaje bez zmian powiązana $\mathrm{z}$ właściwością sądów wojskowych i obowiązuje w stosunku do żołnierzy służby czynnej w sprawach o czyny popełnione $^{26}$ :

1) podczas lub w związku z pełnieniem obowiązków służbowych, w obrębie obiektu wojskowego lub wyznaczonego miejsca przebywania, na szkodę wojska lub z naruszeniem obowiązku wynikającego ze służby wojskowej,

2) za granicą, podczas użycia lub pobytu Sił Zbrojnych Rzeczypospolitej Polskiej poza granicami państwa, w rozumieniu ustawy z dnia 17 grudnia 1998 r. o zasadach użycia lub pobytu Sił Zbrojnych Rzeczypospolitej Polskiej poza granicami państwa.

Przepisy k.k.s dotyczące żołnierzy stosuje się odpowiednio także do żołnierzy sił zbrojnych państw obcych przebywających na terytorium Rzeczypospolitej Polskiej oraz członków ich personelu cywilnego, jeżeli ich przestępstwa skarbowe lub wykroczenia skarbowe pozostają w związku z pełnieniem obowiązków służbowych.

26 Art. 115 w zw. z art. $53 \$ 36$ k.k.s. 


\section{SKUTKi ZMiany WŁaśCIWOŚCi PROCESOWEJ ŻW W SPRAWACH O PRZESTĘPSTWA}

Przed dniem 1 stycznia 2009 r. właściwości sądów wojskowych podlegały ${ }^{27}$ wszystkie sprawy żołnierzy czynnej służby wojskowej. Tym samym zmiana z 1 lipca 2015 r. restytuuje w tym zakresie uprawnienia procesowe Żandarmerii Wojskowej. Ponadto rozszerza je o żołnierzy niebędących w czynnej służbie wojskowej ${ }^{28} \mathrm{w}$ czasie noszenia przez nich mundurów ${ }^{29}$ oraz odznak i oznak wojskowych.

Na szczególną uwagę zasługuje jednak niespotykany wcześniej zakres właściwości procesowej Żandarmerii Wojskowej wprowadzony wobec pracowników wojska i innych osób cywilnych przebywających na terenach lub w obiektach wojskowych ${ }^{30}$.

Żandarmeria Wojskowa będzie właściwa procesowo wobec wszystkich osób cywilnych, jeżeli przestępstwo zostało dokonane na terenie

27 Na podstawie art. 12 Ustawy z dnia 6 czerwca 1997 r. Przepisy wprowadzające Kodeks postępowania karnego, Dz.U. z 1997 r. Nr 89, poz. 556 ze zm.

28 Żołnierzami czynnej służby wojskowej są osoby, które odbywają lub pełnią następujące jej rodzaje: 1) zawodową służbę wojskową, 2) służbę kandydacką (Art. 3 ust. 1 i art. 124 ust. 1 Ustawy z dnia 11 września 2003 r. o służbie wojskowej żołnierzy zawodowych, tekst jedn. Dz.U. z 2014 r., poz. 1414 ze zm.), 3) zasadniczą służbę wojskową, 4) przeszkolenie wojskowe, 5) ćwiczenia wojskowe, 6) służbę przygotowawczą, 7) okresową służbę wojskową, 8) służbę wojskową w razie ogłoszenia mobilizacji i w czasie wojny (Art. 59 Ustawy z dnia 21 listopada 1967 r. o powszechnym obowiązku obrony Rzeczypospolitej Polskiej, tekst jedn. Dz.U. z 2015 r., poz. 144 ze zm.).

29 Zgodnie z treścią art. 10 Ustawy z dnia 21 grudnia 1978 r. o odznakach i mundurach (Dz.U. z 1978 r. Nr 31, poz. 130 ze zm.) mundurem jest ubiór lub jego części służące oznaczeniu przynależności do określonej jednostki organizacyjnej lub wykonywania określonych funkcji albo służby.

30 Zgodnie z treścią art. 3 ust. 5 Ustawy z dnia 21 listopada 1967 r. o powszechnym obowiązku obrony Rzeczypospolitej Polskiej (tekst jedn. Dz.U. z 2015 r. poz. 827) przez jednostkę wojskową rozumie się jednostkę organizacyjną Sił Zbrojnych, funkcjonującą na podstawie nadanego przez Ministra Obrony Narodowej etatu określającego jej strukturę wewnętrzną, liczbę, rodzaje i rangę wszystkich stanowisk służbowych występujących w tej jednostce, jak również liczbę i rodzaje uzbrojenia, środków transportu i innego wyposażenia należnego jednostce, oraz posługującą się pieczęcią urzędową z godłem Rzeczypospolitej Polskiej i nazwą (numerem) jednostki. 
„wojskowym”31, a w przypadku pracowników cywilnych wojska dodatkowo we wszystkich przypadkach, gdy będzie związane $\mathrm{z}$ zatrudnieniem. Ponadto właściwości procesowej podlegają osoby cywilne współdziałające z żołnierzami, pracownikami cywilnymi lub innymi osobami przebywającymi w chwili popełnienia przestępstwa na terenie wojskowym $^{32}$. Na uwagę zasługuje poza tym fakt przyznania uprawnień procesowych Żandarmerii Wojskowej w stosunku do osób cywilnych dopuszczających się popełnienia przestępstwa skierowanego przeciwko życiu lub zdrowiu żołnierza ${ }^{33}$ albo mieniu wojskowemu ${ }^{34}$ (nawet jeżeli sprawca czynu nie jest świadomy, że pokrzywdzonym jest żołnierz służby czynnej lub dowódca jednostki wojskowej).

Jednym $z$ istotnych skutków omawianej zmiany właściwości procesowej ŻW jest przejęcie przez żandarmów postępowań prowadzonych pod nadzorem prokuratur powszechnych, w których akty oskarżenia kierowane są do sądów powszechnych ${ }^{35}$. W ramach tych postępowań Żandarmeria Wojskowa stosuje przepisy o postępowaniu prywatnoskargowym, nakazowym i przyspieszonym, które podlegają wyłączeniu w sprawach podporządkowanych orzecznictwu sądów wojskowych ${ }^{36}$. Prowadzenie spraw $\mathrm{w}$ trybie przyspieszonym powoduje ponadto możliwość stosowania przez ŻW dodatkowej podstawy do zatrzymania osoby podejrzanej ${ }^{37}$.

Należy zgodzić się z ustawodawcą, że wprowadzona zmiana w zakresie właściwości podmiotowo-przedmiotowej Żandarmerii Wojskowej umożliwia realizację zadań, jakie na tej służbie ciążą w zakresie zapewnienia przestrzegania dyscypliny wojskowej oraz lepsze wykorzystanie

31 Bez względu na przyczynę i okoliczności znalezienia się na terenie wojskowym. Por. W. Kotowski, B. KuRZĘPA, Żandarmeria Wojskowa i wojskowe organy porządkowe, Komentarz praktyczny, Warszawa 2005, s. 38.

32 Por. art. 3 ust. 2 pkt 6 ŻWU.

33 Rozdział XIX k.k.

34 Według Autora należy rozpatrywać przestępstwa zawarte w Rozdziałach XXXV k.k. i XLIV k.k., przy czym przestępstwa z rozdziału XLIV k.k. dotyczą tylko pracowników wojska i podlegają orzecznictwu sądów wojskowych na podstawie art. 647 k.k.

35 L. Rusoń, Nowe uprawnienia, «Przegląd Sił Zbrojnych» 1/2015, s. 93.

36 Art. 646 k.p.k.

37 Art. $244 \$ 1$ k.p.k in fine. 
tej formacji jako organu postępowania przygotowawczego. Wydaje się, że nowelizacja art. 312 k.p.k. odciąży Policję od prowadzenia spraw, które ze względu na podmiot przestępstwa mają odrębną specyfikę.

Nie ulega wątpliwości, że Żandarmeria Wojskowa - jako formacja znająca realia służby wojskowej - w sposób najbardziej efektywny jest w stanie wykrywać przestępstwa popełniane przez żołnierzy. Zmiany pozwalają na pełniejsze wykorzystanie jej potencjału, między innymi przez ujednolicenie właściwości tej służby w zakresie czynności operacyjno-rozpoznawczych oraz dochodzeniowo-śledczych. Ma to szczególne znaczenie w zwalczaniu największego obecnie zagrożenia w Siłach Zbrojnych, jakim jest korupcja. Dotychczasowe uregulowania utrudniały skuteczne przeciwdziałanie niniejszemu procederowi z uwagi na ograniczenia procesowe Żandarmerii Wojskowej w stosunku do pracowników cywilnych, którzy nierzadko odpowiadają w jednostkach wojskowych za postępowania przetargowe ${ }^{38}$.

Żandarmeria Wojskowa jest nowoczesną formacją o charakterze policyjnym. Przedstawione skutki rozszerzenia karnoprocesowych uprawnień tej służby wskazują na możliwość szerszej ochrony interesów Sił Zbrojnych, na rzecz których realizuje ona swoje zadania.

The Effects of the Amendment of the Polish Code of Criminal Procedure on the Scope of Powers of the Polish Military Police

\section{Summary}

On 1st July 2015 Art. 321 of the recently amended code of Polish criminal procedure (kodeks posteppowania karnego, k.p.k.) enlarged the scope of powers of the Polish Military Police (Żandarmeria Wojskowa, $\dot{Z} W$ ) in criminal proceedings. In this respect $\dot{Z} W$ now has the powers defined in the Military Police Act (ŻWU), while the respective powers

38 Por. Uzasadnienie Projektu ustawy o zmianie ustawy - Kodeks postępowania karnego, ustawy - Kodeks karny i niektórych innych ustaw, http://orka.sejm.gov.pl/ Druki7ka.nsf/0/96832B0ED113D8FBC1257AB4004F3B04/\%24File/870.pdf (dostęp 20 kwietnia 2015 r.), s. 120-121. 
of military prosecutors and courts have remained unchanged. Since 1st July 2015 ŻW has held the appropriate powers both with respect to soldiers regardless of the circumstances in which they committed an offence, and with respect to civilians violating the law in a military zone. The powers of the Polish Military Police have not been changed in cases of minor and tax offences, and correspond to the jurisdictive powers exercised by military courts. In this article the author analyses the scope of the changes in the powers held by the Polish Military Police regarding procedure in criminal cases, and on the basis of a comparison of the changes with ŻW's structure and duties assesses the effects of the amendment, concluding that their impact goes well beyond the military community.

Pojęcia kluczowe: uprawnienia Żandarmerii Wojskowej, żołnierze, pracownicy cywilni wojska, prawo procesowe, właściwość sądów wojskowych, Siły Zbrojne

Keywords: powers of the Polish military police, soldiers, the army's civilian employees, criminal procedure, jurisdiction of the military courts, the Polish armed forces

\section{Bibliografia:}

Chiniewicz T., Konzeniowski S., PŁonka P., Żandarmeria $w$ działaniach operacyjnych, Mińsk Mazowiecki 2011

GrzegorCzy T.H., Kodeks postępowania w sprawach o wykroczenia. Komentarz, Komentarz do art. 10 k.p.w., System Informacji Prawnej Lex

KaCZOR KIEwiCz D., Forma postępowania przygotowawczego w świetle zmian Kodeksu postępowania karnego z 2013 r., [w:] Reforma prawa karnego, red. I. SePIOŁO-JANKowsKa, Warszawa 2014, s. 463-464

Kotowski W., KurzęPA B., Żandarmeria Wojskowa $i$ wojskowe organy porzadkowe, Komentarz praktyczny, Warszawa 2005

Kubica W., Hatalska-Gorzki A., Stużba policyjna, czy kontrwywiad? Rzecz o teoretycznym sporze kompetencyjnym, «Wojskowy Przegląd Prawniczy» $1 / 2011$

PRUSAK F., Żandarmeria Wojskowa i wojskowe organy porządkowe, [w:] Żandarmeria Wojskowa w systemie bezpieczeństwa wewnętrznego państwa, red. B. Wiśniewski, P. PŁonka, Mińsk Mazowiecki 2010 
Rochnowski A., Hausman M., Analiza kryminalna w Żandarmerii Wojskowej, «Kwartalnik Bellona» 1/2015

Rusoń L., Nowe uprawnienia, «Przegląd Sił Zbrojnych» 1/2015

Wiтczak M., Podstawowe zadania Żandarmerii Wojskowej, [w:] Przeciwdziałanie zagrożeniem niemilitarnym. Zasadnicze aspekty wspótpracy Żandarmerii Wojskowej i Policji, red. P. GuŁa, P. PŁonka, Legionowo 2009 